GRASAS Y ACEITES 67 (1)

January-March 2016, e121

ISSN-L: 0017-3495

doi: http://dx.doi.org/10.3989/gya.0493151

\title{
Solid carbon dioxide to promote the extraction of extra-virgin olive oil
}

\author{
A. Zinnai ${ }^{a}$, F. Venturi ${ }^{\mathrm{a},}$, M.F. Quartacci ${ }^{\mathrm{a}}$, C. Sanmartin ${ }^{\mathrm{a}}$, F. Favati ${ }^{\mathrm{b}}$ and G. Andrich ${ }^{\mathrm{a}}$ \\ ${ }^{a}$ Department of Agriculture, Food and Environment, University of Pisa, Via del Borghetto 80, 56124 Pisa, Italy \\ ${ }^{b}$ Department of Biotechnology, University of Verona, Strada Le Grazie 15, 37134 Verona, Italy \\ ${ }^{\square}$ Corresponding author: francesca.venturi@unipi.it
}

Submitted: 14 April 2015; Accepted: 20 July 2015

SUMMARY: The use of solid carbon dioxide (dry ice) as a cryogen is widespread in the food industry to produce high quality wines, rich in color and perfumes. The direct addition of carbon dioxide to olives in the solid state before milling represents a fundamental step which characterizes this innovative extraction system. At room temperature conditions solid carbon dioxide evolves directly into the air phase (sublimation), and the direct contact between the cryogen and the olives induces a partial solidification of the cellular water inside the fruits. Since the volume occupied by water in the solid state is higher than that in the liquid state, the ice crystals formed are incompatible with the cellular structure and induce the collapse of the cells, besides promoting the diffusion of the cellular substances in the extracted oil, which is thus enriched with cellular metabolites characterized by a high nutraceutical value. Furthermore, a layer of $\mathrm{CO}_{2}$ remains over the olive paste to preserve it from oxidative degradation. The addition of solid carbon dioxide to processed olives induced a statistically significant increase in oil yield and promoted the accumulation of tocopherols in the lipid phase, whereas a not significant increase in the phenolic fraction of the oil occurred.

KEYWORDS: Carbonic snow; Cryomaceration; Extraction index; Extra-virgin olive oil; Product quality

RESUMEN: Dióxido de carbono sólido para promover la extracción del aceite de oliva virgen extra. El uso de dióxido de carbono sólido (hielo seco) como criogénico está muy extendido en la industria alimentaria para producir vinos de alta calidad, ricos en color y perfumes. La adición directa de dióxido de carbono en estado sólido a las aceitunas antes de la molienda representa el paso fundamental que caracteriza este innovador sistema de extracción. En condiciones ambientales el dióxido de carbono sólido evoluciona directamente en la fase de aire (sublimación), y el contacto directo entre el criógeno y las aceitunas induce una solidificación parcial del agua celular dentro de los frutos. Dado que el volumen ocupado por el agua en el estado sólido es mayor que en el estado líquido, los cristales de hielo formados son incompatibles con la estructura celular e inducen el colapso de las células, además de promover la difusión de las sustancias celulares en el aceite extraído, que así, por lo tanto, se enriquece con metabolitos celulares que se caracterizan por un alto valor nutracéutico. Además, una capa de $\mathrm{CO}_{2}$, permanece sobre la pasta de aceitunas para preservar de la degradación oxidativa. La adición de dióxido de carbono sólido a las aceitunas procesadas indujo un aumento estadísticamente significativo en el rendimiento de aceite y promueve la acumulación de tocoferoles en la fase lipídica, mientras que produce un incremento, no significativo, de la fracción fenólica del aceite.

PALABRAS CLAVE: Aceite de oliva virgen extra; Calidad del producto; Criomaceración; Índice de extracción; Nieve carbónica

Citation/Cómo citar este artículo: Zinnai A, Venturi F, Quartacci MF, Sanmartin C, Favati F, Andrich G. 2016. Solid carbon dioxide to promote the extraction of extra-virgin olive oil. Grasas Aceites 67 (1): e121. doi: http://dx.doi. org/10.3989/gya.0493151.

Copyright: (C) 2016 CSIC. This is an open-access article distributed under the terms of the Creative Commons Attribution-Non Commercial (by-nc) Spain 3.0 Licence. 


\section{INTRODUCTION}

Only the oil extracted from olive fruits by a mechanical process at reduced temperatures, characterized by a low acidity and acceptable organoleptic properties, can be named extra-virgin olive oil, a product largely used in the Mediterranean diet (Serra-Majem et al., 2003; Dag et al., 2011; Fregapane and Salvador, 2013). The world consumption of this product is significantly increasing in recent years and this positive trend is related not only to its nutritional and healthpromoting characteristics (Kiritsakis, 1998; Manna et al., 1997; Monteleone et al., 1998; Ranalli et al., 1997; Visoli and Galli, 1998; Mili, 2006; Waterman and Lockwood, 2007; Dag et al., 2011) but also to its sensory properties. In fact, the right balance among saturated, monounsaturated and polyunsaturated fatty acids, along with the significant presence of "minor" components such as aromatic phenolics and tocopherolic compounds (Lazzez et al., 2008; Dag et al., 2011) largely justify its commercial success (Fregapane and Salador, 2013).

The chemical and organoleptic quality enjoyed by extra-virgin olive oil is a function of several factors such as the geographical location of the olive grove, the chemical and microbiological composition of the soil, the evolution of the climatic conditions during fruit ripening, the extraction process adopted, etc. (García et al., 1996; Kiritsakis, 1998; Zamora et al., 2001; Rotondi et al., 2004; Abaza et al., 2005; Ben Temime et al., 2006; Baccouri et al., 2007; Dag et al., 2009). Thus, the application of improved working conditions could potentially offer the real possibility to predict the concentration of phenolic and volatile components in this product and also to modulate its nutraceutical properties as well as the sensorial perception produced.

The cultivar and the ripening degree reached by the olive fruits greatly affect the quality of the extracted oil so that only healthy fruits showing the suitable ripening degree should be processed (Uceda and Frías, 1975; Uceda et al., 1992; Monteleone et al., 1995; Mincione et al., 1996; Mincione, 2007). As for all biological products, the olive characteristics are strongly related not only to the cultivar (genetic variability) but also to the growing techniques and the climatic conditions occurring in the year. Some cultivars are characterized by high phenolic contents (Coratina), while others show more reduced concentrations (Taggiasca). The ripening degree reached by the olive fruits belonging to the same cultivar and grown in the same grove also determines the characteristics of the oil (Dag et al., 2010). In particular, the green or turning color olives give a product marked by bitter notes which can be related to a higher presence of phenolic components (oleocanthal). These more acute and pungent notes are due to tyrosol and its derivatives, particularly deacetoxy-ligstroside.
It is possible to adopt different growing practices during olive production or to employ different working conditions during oil extraction to enhance the content of volatile and/or phenolic components and also to determine the quality of the oil. In fact, a sufficient irrigation of the grove, an early harvest of the fruits, a non-stressful olive pressing, a reduced temperature and a more prolonged kneading phase should be adopted to produce an oil characterized by a high content of volatile components and by a more pronounced aroma as well (Dag et al., 2008). To increase the phenolic fraction and then to produce an oil characterized by greater bitterness and stability, it is necessary to ensure a reduced irrigation of the olive trees, the utilization of less ripe fruits, the use of more efficient crushers able to break also the pit and a kneading phase carried on at a higher temperature for a reduced time. In fact, an increase in temperature also determines an increase in the constant related to the partition equilibrium of phenols between oil and water, and promotes phenol solubility in the oil phase. A prolonged kneading time could promote their enzymatic (phenoloxidase and peroxidase) and/or chemical oxidation, an undesirable transformation which can be sensibly reduced by a strong reduction in the oxygen level in the surrounding atmosphere (Lercker et al., 2007). To succeed in obtaining the desired amounts of volatile and phenolic compounds which greatly affect the quality of an extra-virgin olive oil, it is necessary to effectively control the working variables involved in the malaxation phase (time, temperature and gas composition of the surrounding atmosphere) (Reboredo-Rodriguez et al., 2014). However, the whole process related to oil extraction cannot be reduced only to a simple physical stage because complex bioprocesses can potentially take place in all the phases of the extraction process, and several enzymes able to promote many chemical transformations, including those related to phenolic and volatile compounds, could become catalytically active (Del Caro et al., 2006).

This complex control of all the possible chemical transformations could only partially justify the utilization in the last twenty years of the same traditional procedure to promote the extraction of oil from olive fruits. In fact, only recently has the application of new technologies based on ultrasound and microwave been suggested (Clodoveo, 2013; Clodoveo and Hbaieb, 2013).

Although many experimental results which evidence that the addition of a cryogen (i.e. solid carbon dioxide) to grapes promote the extraction of aromatic and phenolic substances from the fruit skin and produce structured wines of rich fragrance have been already largely reported, this promising technology (cryomaceration) has not yet been tested in olive fruits, where similar results could be potentially obtained. In fact, similar to grapes, the olive 
is a fruit, namely a substrate particularly rich in water and therefore potentially sensible to cryomaceration. The direct contact between the cryogen and the olives induces a partial solidification of the cellular water and an increase in the volume occupied by water. The consequent laceration of the cellular membranes (cellular crash) makes the diffusion of oil and other cellular compounds (phenols, aromatic substances, etc.) in the liquid phase easier and thus facilitates their extraction from cryomacerated fruits.

Moreover, the lower values of temperature reached by adding carbonic snow and the relevant amount of gas evolved because of the interaction between solid $\mathrm{CO}_{2}\left(-78^{\circ} \mathrm{C}\right.$ at atmospheric pressure) and the olives/olive paste (initially at room temperature) induce the formation of a sort of protective inert layer over the processed olives. This gaseous layer would be able to prevent oxidation and then reduce the loss of antioxidants like phenols (Di Giovacchino et al., 2002) without compromising the accumulation of some components responsible for flavor (Zinnai et al., 2007).

Although the addition of a cryogen to promote oil extraction could slightly increase the production cost, this innovative technology is able to produce a high quality oil characterized by a strong link with the olives used as well as their production area. Thus, the product would be easily identifiable by the modern consumer who is very health-conscious and critically evaluates the nutritional and organoleptic quality of food.

\section{MATERIALS AND METHODS}

The extraction was carried out using a micro oil mill (Oliomio Baby ${ }^{\circledR}$, Toscana Enologica Mori) able to mill $20-30 \mathrm{~kg}$ of olives. This apparatus was suitably modified to allow the direct addition of solid carbon dioxide (carbonic snow) to the olive fruits and/or to the paste coming from their milling. The main process steps followed by this micro oil mill can be summarized as follows: olives, properly cleaned and washed, were poured into the receiving hopper where a screw fed a crusher equipped with a hollow knife impeller. The produced paste fell into a lower mixer, where a helicoid shaped stirrer promoted its malaxation. The temperature reached by the paste was maintained in the desired range by a thermal regulation system (a temperature sensor put inside the olive paste, connected with a heat exchanger). The suitable flow of olive paste was then sent to a biphasic decanter by a pump equipped with a speed change gear. The decanter (4200 rpm) favored the separation of oil from the olive pomace mixed with water (vegetable water plus the water potentially added through a flow-meter in order to induce a more efficient separation). The separation efficiency of the decanter can be modulated by a suitable regulation of the nozzles, which determines the point of oil picking and then also the degree of its contamination by vegetable water.

At the end of the extraction process, the decanter was washed with an amount of water measured by a flow-meter to ensure the total spillage of the oil coming out of the olive fruits. Thus, it was possible to verify the mass balance of oil by equation 1 :

Mfruits $\times$ OFfruits $=$ Mpomace $\times$ OFpomace + MOE Eq. 1

where Mfruits $=$ mass of fruits $(\mathrm{kg})$; OFfruits $=$ oil fraction of the olive fruits (OFfruits=weight of oil/weight of fruits); Mpomace $=$ mass of pomace; $O F$ pomace $=$ oil fraction in the pomace (OFpomace=weight of oil/ weight of pomace); $\mathrm{MOE}=$ mass of oil $(\mathrm{kg})$, and to determine the production yield (PY) by equation 2 :

$\mathrm{PY}=\mathrm{MOE} /($ Mfruits $\times$ OFfruits)

Eq. 2

The main characteristics of the fruits (carpological properties, maturity index, chemical composition) and of the pomace were determined by a solvent extractor (SER 148-3 Velp Scientifica) (oil content) and by the analytical procedures reported in the literature (Uceda and Frias, 1975; Ryan and Robards, 1998; Mincione, 2007).

About $30 \mathrm{~kg}$ of olive fruits belonging to different cultivars (Leccino, Frantoio, Correggiolo, Itrana and Coratina), hand-picked and accurately washed, were initially charged inside the hopper to be mixed with carbonic snow or not.

To obtain a significant comparison among data on the oil extracted after adding or not solid $\mathrm{CO}_{2}$, the processed olive fruits were previously accurately mixed to ensure in both cases (with and without addition of cryogen) a comparable feed.

Table 1 reports the working condition adopted for a generic experimental run carried out on with and without the addition of solid carbon dioxide during the crushing phase.

The analytical characterization of the oils (acidity, peroxide number, spectrophotometer indexes, total phenols, carotenoids, tocopherols, chlorophyll) was carried out according to the conventional

TABLE 1. Working parameters adopted for a generic experimental run carried out on adding cryogen or not

\begin{tabular}{llcc}
\hline & & Cryo & Traditional \\
\hline $\mathrm{kg}$ of added $\mathrm{CO}_{2} \cdot \mathrm{kg}^{-1}$ of olives & $(\%)$ & $10.0 \div 20.0$ & 0 \\
Olive temperature & $\left({ }^{\circ} \mathrm{C}\right)$ & $11.5 \div 2.1$ & 10.9 \\
Paste temperature & $\left({ }^{\circ} \mathrm{C}\right)$ & 23.9 & 24.0 \\
Malaxation time & $(\mathrm{s})$ & 2400 & 2400 \\
Extraction time & $(\mathrm{s})$ & 4900 & 4300 \\
$\mathrm{~kg}$ of added water $\cdot \mathrm{kg}^{-1}$ of olives & $(\%)$ & 8.5 & 9.3 \\
\hline
\end{tabular}


analytical procedures reported in the literature (Gutiérrez Rosales et al., 1992; Pokorny et al., 1995; Capella et al., 1997; Tateo and Bononi, 2004).

The experimental data were evaluated according to the statistical methods reported in the literature (Snedecor and Cochran, 1979; Ryan and Robards, 1998).

\section{RESULTS AND DISCUSSION}

Table 2 reports some characteristics of olives used to produce extra-virgin oil by adding carbonic snow or not. Depending on the cultivar used, it is possible to identify five different groups of fruits. While group A represents a mixture of olives belonging to two different cultivars (Frantoio and Leccino), the others are formed by fruits belonging to only one cultivar. Although the olives of groups $\mathrm{C}$ and $\mathrm{D}$ belong to the same cultivar (Coratina) they were produced in two different Italian regions (Toscana and Basilicata, respectively). Moreover, the fruits belonging to the same group but picked up at different ripening stages (five sampling dates for group A and three for D) are characterized by chemical compositions which are statistically different as shown in Table 2.

The experimental data related to the macrocomposition of the olives were affected by a high variability as a function of the sampling date (compare data related to the five runs of group A and the three of group D), particularly those of group $\mathrm{A}$, in which the fruits belong to two different cultivars (Leccino and Frantoio) and reach their ripening stages at different dates. Thus, the first run of group A (A1) was constituted by a relevant number of olives belonging to the cultivar Leccino which reaches its ripeness before the other (Frantoio), while the fraction of these olives decreased when the sampling date increased. This could explain the experimental values assumed by the maturity indexes and the moisture percentages of the other runs of group A. Concerning the samples constituted by fruits belonging to the same cultivar (compare runs D1, D2 and D3), these apparent contradictions do not seem to occur. In fact, to the increasing values assumed by the maturity index corresponds to the expected decrease in water content and a corresponding increase in oil percentage.

The olives belonging to the late cultivar Itrana were collected and milled during the spring of the following year, but were less intact and healthy than those of the other cultivars collected the previous autumn.

To ensure the experimental utilization of comparable batches of olives, samples of fruits collected at the same date and in the same orchard were accurately mixed to obtain a homogeneous distribution of fruits before dividing them in two or more equivalent portions. These comparable groups of olives were milled adopting the same working conditions, but adding carbonic snow or not to determine the effect induced by the addition of the cryogen. Table 3 reports the experimental data related to the extraction yields (weight of oil/weight of fruits) obtained by adding $\left(\mathrm{Y}+\mathrm{CO}_{2, \mathrm{~s}}\right)$ or not $\left(\mathrm{Y}-\mathrm{CO}_{2, \mathrm{~s}}\right)$ carbonic snow. Moreover, to highlight the possible effect induced by the cryogen addition, the values of the percentage difference $(\Delta \mathrm{Y} \%)$ occurring between the two yields obtained by adding carbonic snow or not are also reported in Table 3 .

Although in two cases (A3 and $\mathrm{C} 1)$ the amount of oil extracted after adding carbonic snow was lower than that obtained without the addition, only positive values of $\Delta \mathrm{Y} \%$ were obtained in all the other experimental determinations, and in some cases the difference occurring between the extraction yields

TABLE 2. Ripening date, maturity index and macro-compositions (mean values of percentages related to oil, moisture and defatted dry residue together with the related confidence interval; $\mathrm{p}=0.05$ ) of the groups of olive fruits used in the experimental determinations

\begin{tabular}{lccccccc}
\hline Olive group & $\begin{array}{c}\text { Ripening } \\
\text { date }\end{array}$ & Run & $\begin{array}{c}\text { Maturity } \\
\text { Index (0 } \div \text {-7) }\end{array}$ & Cultivars & $\begin{array}{c}\text { Moisture } \\
\%\end{array}$ & $\begin{array}{c}\text { Oil content } \\
\%\end{array}$ & $\begin{array}{c}\text { Defatted dry } \\
\text { residue \% }\end{array}$ \\
\hline A & $08 / 11 / 2010$ & A1 & 3.0 & Frantoio, & $57.1 \pm 0.7$ & $14.2 \pm 0.7$ & $28.7 \pm 1.4$ \\
& $11 / 11 / 2010$ & A2 & 3.8 & Leccino & $52.1 \pm 0.2$ & $16.3 \pm 0.4$ & $31.6 \pm 0.6$ \\
& $04 / 12 / 2010$ & A3 & 3.6 & & $53.5 \pm 0.6$ & $19.0 \pm 0.3$ & $27.4 \pm 0.9$ \\
& $07 / 12 / 2010$ & A4 & 4.0 & & $52.9 \pm 0.4$ & $20.3 \pm 0.5$ & $26.8 \pm 0.9$ \\
& $09 / 12 / 2010$ & A5 & 5.1 & & $48.2 \pm 0.3$ & $24.2 \pm 0.4$ & $27.6 \pm 0.7$ \\
B & $12 / 11 / 2010$ & B1 & 1.0 & Frantoio & $50.3 \pm 0.6$ & $18.4 \pm 1.3$ & $31.2 \pm 1.9$ \\
C & $18 / 11 / 2010$ & C1 & 2.3 & Coratina & $49.2 \pm 0.6$ & $15.9 \pm 0.7$ & $34.8 \pm 1.3$ \\
D & $15 / 11 / 2010$ & D1 & 2.6 & Coratina & $61.4 \pm 0.3$ & $18.3 \pm 0.2$ & $22.2 \pm 0.3$ \\
& $29 / 11 / 2010$ & D2 & 2.8 & & $55.8 \pm 0.9$ & $19.4 \pm 0.2$ & $27.7 \pm 1.1$ \\
& $13 / 12 / 2010$ & D3 & 4.2 & & $53.2 \pm 0.1$ & $23.5 \pm 0.1$ & $23.2 \pm 0.2$ \\
E & $16 / 04 / 2011$ & E & 4.6 & Itrana & $59.5 \pm 0.4$ & $16.2 \pm 0.2$ & $24.3 \pm 0.6$ \\
\hline
\end{tabular}


TABLE 3. Extraction yields ( $\mathrm{kg}$ of oil $\cdot \mathrm{kg}^{-1}$ of olives, $\%$ ) obtained adopting the same experimental conditions but adding $\left(\mathrm{Y}+\mathrm{CO}_{2, \mathrm{~s}}\right)$ or not $\left(\mathrm{Y}-\mathrm{CO}_{2, \mathrm{~s}}\right)$ carbonic snow to the same portion of fruits together with the value assumed by the difference percentage $\left[\Delta \mathrm{Y} \%=\left(\mathrm{Y}+\mathrm{CO}_{2, \mathrm{~s}}-\mathrm{Y}-\mathrm{CO}_{2, \mathrm{~s}}\right) \times 100 / \mathrm{Y}-\mathrm{CO}_{2, \mathrm{~s}}\right]$

\begin{tabular}{|c|c|c|c|}
\hline Run & $\mathrm{Y}+\mathrm{CO}_{2(\mathrm{~s})}$ & $\mathrm{Y}-\mathrm{CO}_{2(\mathrm{~s})}$ & $\begin{array}{c}\Delta \mathrm{Y}_{0}=\left(\mathrm{Y}+\mathrm{CO}_{2, \mathrm{~s}}-\right. \\
\left.\mathrm{Y}-\mathrm{CO}_{2, \mathrm{~s}}\right) \times 100 / \mathrm{Y}-\mathrm{CO}_{2, \mathrm{~s}}\end{array}$ \\
\hline $\mathrm{A} 1,1^{*}$ & 12.2 & 11.0 & 10.9 \\
\hline $\mathrm{A} 1,2^{*}$ & 13.0 & 11.8 & 10.2 \\
\hline A2 & 16.3 & 13.2 & 23.5 \\
\hline A3 & 15.5 & 15.7 & -1.3 \\
\hline A4 & 16.0 & 14.2 & 12.7 \\
\hline A5 & 15.2 & 14.6 & 4.1 \\
\hline B1 & 15.8 & 15.2 & 4.0 \\
\hline $\mathrm{C} 1$ & 12.0 & 12.8 & -6.2 \\
\hline D1 & 14.8 & 14.5 & 2.2 \\
\hline D2 & 16.4 & 15.0 & 9.3 \\
\hline D3 & 17.3 & 16.2 & 6.8 \\
\hline $\mathrm{Ea}^{* *}$ & 8.8 & 8.5 & 3.5 \\
\hline $\mathrm{Eb}^{* *}$ & 9.2 & 8.5 & 8.2 \\
\hline $\mathrm{Ec}^{* *}$ & 12.6 & 8.5 & 48.2 \\
\hline
\end{tabular}

evaluated after adding carbonic snow or not was particularly significant $(23.5 \%$ for A2 and $48.2 \%$ for Ec).

Moreover, if increasing amounts of carbonic snow $(0,3,4.5$ and $6 \mathrm{~kg})$ were added to the same amount $(30 \mathrm{~kg})$ of olives (E group) an increase in oil yield was always obtained.

The mean value and the related confidence interval of the percentage differences between extraction yields obtained after adding cryogen to the olive fruits or not were also determined $\left(\Delta \mathrm{Y}^{\circ} \%\right.$ mean \pm c.i. $\left.=9.3 \pm 1.9 \% ; \mathrm{p}=0.05\right)$. To ensure a normal distribution of the experimental data, the statistical analysis was carried out with the corresponding values of arcsin $\sqrt{ } \Delta \mathrm{Y} \%$ (Snedecor and Cochran, 1979). The addition of carbonic snow to the olive fruits produced an increase in oil of about $9 \%$. Thus, if without any cryogen addition $16 \mathrm{~kg}$ of extra-virgin olive oil can be extracted from $100 \mathrm{~kg}$ of olive fruits, from the same amount of the same fruits more than $17 \mathrm{~kg}$ of product can be obtained following carbonic snow addition.

With regards to the qualitative parameters of the oil extracted after adding carbonic snow or not, Table 4 reports the values for acidity, peroxide number and the spectrophotometric indexes (K232, $\mathrm{K} 270$ and $\Delta \mathrm{K})$, together with their related confidence interval $(\mathrm{p}=0.05)$. Being that the values calculated for $\Delta \mathrm{K}(\mathrm{K} 268-(\mathrm{K} 262+\mathrm{K} 274) / 2)$ are lower than 0.01 for almost all the oils, these data are not reported in Table 4. Only two samples of oil extracted from olive fruits belonging to the Itrana cultivar which showed values greater than or comparable to this limit $(\triangle \mathrm{KEa}$ $(\Delta \mathrm{K}=0.01 \pm 0.05$ and $\Delta \mathrm{KEc}=-0.08 \pm 0.15)$ were found.
With the exception of oils from olives belonging to this particular cultivar (Ea, Eb and Ec) which, as previously reported, were less intact and healthy than the other fruits, all the oils were characterized by better analytical values, not only of those expected for an extra-virgin olive oil but also for a PDO product (Table 4). Moreover, no significant differences occurred among the values determined for these qualitative indexes as a function of the extraction technology adopted or of the possible addition of carbonic snow. In any case, the micro oil mill used was able to produce high quality extra-virgin olive oil without any cryogen addition, so any possible quality improvement due to the use of carbonic snow would assume a more significant meaning.

Among all the quality indexes determined in the oils, only those related to the contents of tocopherols and total phenols varied significantly following the addition of carbonic snow to the olive fruits. Table 5 reports the amounts of tocopherols and total phenols co-extracted with oil adopting the same experimental conditions but adding (Toc/Phtot $+\mathrm{CO}_{2, \mathrm{~s}}$ ) or not (Toc/Phtot- $\mathrm{CO}_{2, \mathrm{~s}}$ ) carbonic snow to olives belonging to the same homogeneous group of fruits.

While for tocopherols (vitamin E), with the only exception of the D1 sample, a clear increase in the extraction yield was always obtained; the effect induced by cryogen on the extraction of total phenols was affected by a higher variability. In fact, for many samples an increase in total phenol concentrations (A1.1, A2, A3, A5, B1, C1, Ea, Eb and Ec) was observed when cryogen was used, but in some cases (A1.2, A4, D1, D2, D3) the opposite situation occurred. To evaluate the effect induced by cryogen addition on the co-extraction of tocopherols and total phenols with oil, the same statistical procedure adopted to analyze the experimental data concerning the oil yield was used. A positive mean value of percentage difference was obtained for both tocopherols $(\Delta \mathrm{Toc} \%$ mean $=6.0)$ and total phenols $(\Delta$ Phtot $\%$ mean $=5.1)$, but while for tocopherols a confidence interval (c.i. $=0.6 ; p=0.05$ ) lower than the mean value was obtained, for total phenols the confidence interval (c.i. $=10.6 ; p=0.05$ ) resulted higher than the corresponding mean value. Thus, while the addition of carbonic snow determined a significant increase in tocopherol content in the oil, the increase in total phenols did not prove to be statistically significant. As reported in the literature (Clodoveo, 2013; Clodoveo and Hbaieb, 2013; Reboredo-Rodriguez et al., 2014), phenol extraction is not promoted by working at reduced temperatures because the constant related to the partition equilibrium of phenols between oil and water decreases substantially. On the contrary, the direct contact of carbonic snow with the olive fruits induces a partial solidification of fruit water and then the laceration of the cellular membranes (cellular crash) 
TABLE 4. The values determined for total acidity, number of peroxides and spectrophotometric indexes (mean \pm c.i.; $\mathrm{p}=0.05)$ in the oils extracted from different samples of olive fruits tested, adding $(+)$ or not (-) carbonic snow

\begin{tabular}{|c|c|c|c|c|c|c|c|c|}
\hline \multirow[b]{2}{*}{ Run } & \multicolumn{2}{|c|}{$\begin{array}{c}\begin{array}{c}\text { oil acidity ( } \mathrm{g} \text { of oleic } \\
\text { acid } \cdot 100 \mathrm{~g}^{-1} \text { of oil) }\end{array} \\
\end{array}$} & \multicolumn{2}{|c|}{$\begin{array}{l}\text { Number of peroxides } \\
\left(\mathrm{mEq} \mathrm{O}_{2} \cdot \mathrm{kg}^{-1} \text { oil }\right)\end{array}$} & \multicolumn{2}{|c|}{$K_{232}$} & \multicolumn{2}{|c|}{$\mathbf{K}_{270}$} \\
\hline & + & - & + & - & + & - & + & - \\
\hline $\mathrm{A} 1,1^{*}$ & $0.36 \pm 0.01$ & $0.63 \pm 0.03$ & $4.82 \pm 0.58$ & $6.53 \pm 0.01$ & $1.37 \pm 0.15$ & $1.44 \pm 0.22$ & $0.07 \pm 0.01$ & $0.10 \pm 0.03$ \\
\hline $\mathrm{A} 1,2^{*}$ & $0.67 \pm 0.01$ & $0.75 \pm 0.03$ & $7.86 \pm 0.52$ & $6.52 \pm 0.34$ & $1.26 \pm 0.05$ & $1.27 \pm 0.07$ & $0.10 \pm 0.01$ & $0.12 \pm 0.03$ \\
\hline $\mathrm{A} 2$ & $0.19 \pm 0.01$ & $0.18 \pm 0.01$ & $7.45 \pm 0.10$ & $7.44 \pm 0.30$ & $1.64 \pm 0.10$ & $1.57 \pm 0.10$ & $0.15 \pm 0.02$ & $0.13 \pm 0.01$ \\
\hline A3 & $0.26 \pm 0.01$ & $0.25 \pm 0.01$ & $9.36 \pm 0.42$ & $7.51 \pm 0.74$ & $1.33 \pm 0.02$ & $1.91 \pm 0.17$ & $0.11 \pm 0.02$ & $0.14 \pm 0.01$ \\
\hline A4 & $0.55 \pm 0.01$ & $0.54 \pm 0.01$ & $7.14 \pm 0.38$ & $6.80 \pm 0.57$ & $1.78 \pm 0.12$ & $1.04 \pm 0.14$ & $0.17 \pm 0.03$ & $0.11 \pm 0.01$ \\
\hline A5 & $0.68 \pm 0.06$ & $0.61 \pm 0.03$ & $8.19 \pm 0.30$ & $8.22 \pm 0.50$ & $1.60 \pm 0.15$ & $1.62 \pm 0.12$ & $0.16 \pm 0.02$ & $0.14 \pm 0.01$ \\
\hline B1 & $0.32 \pm 0.01$ & $0.29 \pm 0.02$ & $6.75 \pm 0.18$ & $6.26 \pm 0.63$ & $1.45 \pm 0.13$ & $1.52 \pm 0.14$ & $0.09 \pm 0.02$ & $0.09 \pm 0.03$ \\
\hline $\mathrm{C} 1$ & $0.40 \pm 0.02$ & $0.26 \pm 0.03$ & $5.91 \pm 0.68$ & $7.08 \pm 0.47$ & $1.43 \pm 0.09$ & $1.61 \pm 0.08$ & $0.11 \pm 0.02$ & $0.12 \pm 0.01$ \\
\hline D1 & $0.26 \pm 0.01$ & $0.21 \pm 0.02$ & $9.25 \pm 0.70$ & $9.06 \pm 0.10$ & $1.54 \pm 0.14$ & $1.69 \pm 0.13$ & $0.13 \pm 0.04$ & $0.15 \pm 0.01$ \\
\hline D2 & $0.21 \pm 0.04$ & $0.22 \pm 0.02$ & $8.90 \pm 1.22$ & $9.13 \pm 0.58$ & $1.59 \pm 0.09$ & $1.66 \pm 0.23$ & $0.13 \pm 0.04$ & $0.15 \pm 0.03$ \\
\hline D3 & $0.29 \pm 0.01$ & $0.32 \pm 0.01$ & $5.29 \pm 0.12$ & $6.52 \pm 0.68$ & $1.34 \pm 0.07$ & $1.60 \pm 0.14$ & $0.10 \pm 0.02$ & $0.12 \pm 0.01$ \\
\hline $\mathrm{Ea}^{* *}$ & $0.53 \pm 0.01$ & $0.37 \pm 0.01$ & $11.08 \pm 1.74$ & $10.93 \pm 0.64$ & $2.52 \pm 0.10$ & $2.46 \pm 0.25$ & $0.04 \pm 0.01$ & $0.14 \pm 0.02$ \\
\hline $\mathrm{Eb}^{* *}$ & $1.64 \pm 0.02$ & $=$ & $10.55 \pm 1.50$ & $=$ & $2.00 \pm 0.02$ & $=$ & $0.07 \pm 0.01$ & $=$ \\
\hline $\mathrm{Ec}^{* *}$ & $1.65 \pm 0.01$ & $=$ & $10.17 \pm 2.41$ & $=$ & $1.67 \pm 0.15$ & $=$ & $0.12 \pm 0.02$ & $=$ \\
\hline$\circ$ & \multicolumn{2}{|c|}{$<0.80$} & \multicolumn{2}{|c|}{$<20.00$} & \multicolumn{2}{|c|}{$<2.50$} & \multicolumn{2}{|c|}{$<0.22$} \\
\hline ○ & \multicolumn{2}{|c|}{$\leq 0.50$} & \multicolumn{2}{|c|}{$<12.00$} & \multicolumn{2}{|c|}{$<2.20$} & \multicolumn{2}{|c|}{$<0.20$} \\
\hline
\end{tabular}

*A1,1 and A1,2 represent two replications of oil extraction carried out adding carbonic snow or not to similar samples of olive fruits (A1).

**experimental runs carried out adding different amounts $(0 ; 3 ; 4.5 ; 6 \mathrm{~kg})$ of carbonic snow to $30 \mathrm{~kg}$ of olive fruits belonging to the same lot of olives ( $\mathrm{E}=\mathrm{Itrana}$ cultivar).

$=$ experimental value equal to that reported for Ea.

${ }^{\circ}$ Values established for an extra virgin olive oil (Reg 2568/91); ${ }^{\circ}$ Values requested by the disciplinary of a PDO extra virgin olive oil.

TABLE 5. Amounts of tocopherols and total phenols co-extracted with oil adopting the same experimental conditions but adding $\left(\mathrm{Toc} / \mathrm{Ph}_{\mathrm{tot}}+\mathrm{CO}_{2, \mathrm{~s}}\right)$ or not $\left(\mathrm{Toc} / \mathrm{Ph}_{\mathrm{tot}}-\mathrm{CO}_{2, \mathrm{~s}}\right)$ carbonic snow to the same lot of fruits together with the value of the difference in percentage $\left[\Delta \mathrm{Toc} / \mathrm{Ph}_{\mathrm{tot}} \%=\left(\mathrm{Toc} / \mathrm{Ph}_{\mathrm{tot}}+\mathrm{CO}_{2, \mathrm{~s}}-\mathrm{Toc} / \mathrm{Ph}_{\mathrm{tot}}-\mathrm{CO}_{2, \mathrm{~s}}\right) \times 100 / \mathrm{Toc} / \mathrm{Ph}_{\mathrm{tot}}-\mathrm{CO}_{2, \mathrm{~s}}\right]$

\begin{tabular}{|c|c|c|c|c|c|c|}
\hline Run & $\mathrm{Toc}+\mathrm{CO}_{2, \mathrm{~s}}(\mathrm{ppm})$ & Toc- $\mathrm{CO}_{2, \mathrm{~s}}(\mathrm{ppm})$ & $\Delta \mathrm{Toc} \%$ & Phtot $+\mathrm{CO}_{2, \mathrm{~s}}(\mathrm{ppm})$ & Phtot-COO ${ }_{2, \mathrm{~s}}(\mathrm{ppm})$ & $\Delta$ Phtot $\%$ \\
\hline A1.1* & 206 & 198 & 4.0 & 341 & 335 & 1.8 \\
\hline $\mathrm{A} 1.2^{*}$ & 220 & 198 & 11.1 & 227 & 251 & -9.6 \\
\hline $\mathrm{A} 2$ & 193 & 181 & 6.6 & 502 & 450 & 11.6 \\
\hline A3 & 197 & 189 & 4.2 & 248 & 238 & 4.2 \\
\hline A4 & 179 & 174 & 2.9 & 186 & 251 & -25.9 \\
\hline A5 & 184 & 170 & 8.2 & 556 & 501 & 11.0 \\
\hline B1 & 135 & 125 & 8.0 & 537 & 428 & 25.5 \\
\hline $\mathrm{C} 1$ & 255 & 221 & 15.4 & 557 & 498 & 11.8 \\
\hline D1 & 294 & 294 & 0.0 & 443 & 466 & -4.9 \\
\hline D2 & 261 & 253 & 3.2 & 445 & 553 & -19.5 \\
\hline D3 & 249 & 248 & 0.4 & 333 & 475 & -29.9 \\
\hline $\mathrm{Ea}^{* *}$ & 294 & 257 & 14.4 & 44 & 36 & 22.2 \\
\hline $\mathrm{Eb}^{* *}$ & 291 & 257 & 13.2 & 46 & 36 & 27.8 \\
\hline $\mathrm{Ec}^{* *}$ & 286 & 257 & 11.3 & 54 & 36 & 50.0 \\
\hline
\end{tabular}

*A1,1 and A1,2 represent two replications of oil extraction carried out adding carbonic snow or not to similar samples of olive fruits (A1).

**experimental runs carried out adding different amounts $(0 ; 3 ; 4.5 ; 6 \mathrm{~kg})$ of carbonic snow to $30 \mathrm{~kg}$ of olive fruits belonging to the same lot of olives ( $\mathrm{E}=$ Itrana cultivar). 
which makes the diffusion of all the compounds easier and therefore of phenols in the liquid phase as well. These considerations could partially justify the results obtained: the cellular crash could have increased phenol extraction ( $\Delta$ Phtot $\%$ mean $>0)$, while the reduced temperature would have induced phenol accumulation in the water phase; the rate of diffusion could be due to the amount of liquid water actually present during the phases of malaxation and centrifugation. Moreover to a preliminary and a non-professional sensory evaluation, the oil appeared to have a richer aroma and a more complex and varietal taste.

\section{CONCLUSIONS}

According to these preliminary results, the addition of carbonic snow to olive fruits constitutes a promising new technology which allows to significantly increase the yield of oil extracted from olive fruits to produce a high quality product (extra-virgin olive oil) characterized by an increased content of vitamin E (tocopherols) and also of phenols. Further research must be carried on in the near future to evaluate the real potential of this innovative technology. In particular, this research will be aimed to determine the best ratio between cryogen and olive fruits as well as the optimum values of time and temperature to employ during the extraction process, particularly during malaxation, the phase which greatly affects the qualitative characteristics of the extra-virgin olive oil produced.

\section{REFERENCES}

Abaza L, Taamalli W, Ben Temime S, Daoud D, Gutiérrez F, Zarrouk M. 2005. Natural antioxidant composition as correlated to stability of some Tunisian virgin olive oils. Riv. Ital. Sost. Grasse, 82, 12-18.

Baccouri B, Ben Temime S, Taamalli W, Daoud D, M'sallem M, Zarrouk M. 2007. Analytical characteristics of virgin olive oils from two new varieties obtained by controlled crossing on Meski variety. J. Food Lipids, 14, 19-34. http://dx.doi. org/10.1111/j.1745-4522.2006.00067.x.

Ben Temime S, Taamalli W, Bacccouri B, Abaza L, Daoud D, Zarrouk M. 2006. Changes in olive oil quality of Chétoui variety according to origin of plantation. J. Food Lipids, 13, 88-99. http://dx.doi.org/10.1111/j.1745-4522.2006.00036.x.

Capella P, Fedeli E, Bonaga G, Lercker G. 1997. Il Manuale degli Oli e dei Grassi. Ed. Tecniche nuove, Milano. ISBN 887081 9795.

Clodoveo ML. 2013. New advances in the development of innovative virgin olive oil extraction plants: Looking back to see the future. Food Res. Int. 54, 726-729. http://dx.doi. org/10.1016/j.foodres.2013.08.020

Clodoveo ML, Hbaieb RH. 2013. Beyond the traditional virgin olive oil extraction systems: Searching innovative and sustainable plant engineering solutions. Food Res. Int. 54, 1926-1933. http://dx.doi.org/10.1016/j.foodres.2013.06.014.

Dag A, Ben-David EA, Fiume P, Perri E. 2009. Cultivation: Problems and Perspectives. Sixth Framework Programme Priority 5; Food Quality and Safety Priority. Call 4-C; MAC-oils. The Scientific Handbook. Avellino. Italy, 1-55.

Dag A, Ben-Gal A, Yermiyahu U, Basheer L, Nir Y, Kerem Z. 2008. The effect of irrigation level and harvest mechanization on virgin olive oil quality in a traditional rain-fed
"Souri" olive orchard converted to irrigation. J. Sci. Food Agric. 88, 1524-1528. http://dx.doi.org/10.1002/jsfa.3243.

Dag A, Bustan A, Avni A, Zipori I, Lavee S, Riov J. 2010. Timing of fruit removal affects concurrent vegetative growth and subsequent return bloom and yield in olive (Olea europaea L.). Sci. Hort. 123, 469-472. http://dx.doi. org/10.1016/j.scienta.2009.11.014

Dag A, Keremb Z, Yogevb N, Zipori I, Laveec S, Ben-Davida E. 2011. Influence of time of harvest and maturity index on olive oil yield and quality. Sci. Hort. 127, 358-366. http:// dx.doi.org/10.1016/j.scienta.2010.11.008.

Del Caro A, Vacca V, Poiana M, Fenu P, Piga A. 2006. Influence of technology. storage and exposure on components of extra virgin olive oil (Bosana cv) from whole and de-stoned fruits. Food Chem. 98, 311-316. http://dx.doi.org/10.1016/j. foodchem.2005.05.075.

Di Giovacchino L, Sestili S, Di Vincenzo D. 2002. Influence of olive processing on virgin olive oil quality. Eur. J. Lipid Sci. Tech. 104, 587-601.

Fregapane G, Salvador MD. 2013. Production of superior quality extra virgin olive oil modulating the content and profile of its minor components. Food Res. Int. 54, 1907-1914. http://dx.doi.org/10.1016/j.foodres.2013.04.022.

García JM, Seller S, Pérez-Camino MC. 1996. Influence of fruit ripening on olive oil quality. J. Agric. Food Chem. 44. 3516-3520. http://dx.doi.org/10.1021/jf950585u.

Gutiérrez-Rosales F, Perdiguero S, Gutiérrez R, Olías JM. 1992. Evaluation of bitter taste in virgin olive oil. J. Am. Oil Chem. Soc. 69, 394-395. http://dx.doi.org/10.1007/BF02636076.

Kiritsakis AK. 1998. Olive Oil Handbook. AOCS Press. Champaign. IL. ISBN: 978-1-4614-7776-1 (Print) 978-1-4614-7777-8 (Online); http://dx.doi.org/10.1007/978-1-4614-7777-8.

Lazzez A, Perri E, Caravita MA, Khlif M, Cossentini M. 2008. Influence of olive maturity stage and geographical origin on some minor components in virgin olive oil of the Chemlali Variety. J. Agric. Food Chem. 56, 982-988. http://dx.doi.org/10.1021/jf0722147.

Lercker G, Bendini A, Cerretani L. 2007. Qualità, composizione e tecnologia di produzione degli oli vergini di oliva. Prog. Nutr. 9, 134-148.

Manna C, Galletti P, Cucciolla V, Moltedo O, Leone A, Zappia V. 1997. The protective effect of the olive oil polyphenol (3.4-dihydroxyphenyl)-ethanol counteracts reactive oxygen metabolite-induced cytotoxicity in Caco-2 cells. J. Nutr. 127, 286-292. PMID: 9039829.

Mili S. 2006. Olive oil marketing in non-traditional markets: prospects and strategies. New Medit. 5, 27-37.

Mincione A, Runcio A, Valenzise R, Sorgonà L, Santacaterina S, Poiana M. 2007. Ricerche sull'olio di oliva monovarietali. Nota XVI. Contributo alla caratterizzazione dell'olio estratto dalle olive della cv Frantoio coltivata in due diversi areali della Provincia di Reggio Calabria. Riv. Ital. Sost. Grasse, 84, 133-156.

Mincione B, Poiana M, Giuffrè AM, Modafferi V, Giuffrè F. 1996. Ricerche sugli oli monovarietali. Nota II. Caratterizzazione dell'olio di Peranzana. Riv. Ital. Sost. Grasse. 73, 245-257.

Mincione B. 2007. L'olio di Oliva vergine della provincia di Reggio Calabria prodotto da cultivar non autoctone - Caratteristiche Merceologiche e Qualitative. UNIRC (CEN.S.A.) Laruffa Editore. 105-129. ISBN 9788872213193.

Monteleone E, Caporale G, Carlucci A, Pagliarini E. 1998. Optimisation of extra virgin olive oil quality. J. Sci. Food Agric. 77, 31-37.

Monteleone E, Caporale G, Lencioni L, Favati F, Bertuccioli M. 1995. Optimization of virgin olive oil quality in relation to fruit ripening and storage. Dev. Food Sci. 37, 397-418. http://dx.doi.org/10.1016/S0167-4501(06)80168-8.

Pokorny J, Kalinova L, Dysseler P. 1995. Determination of chlorophyll pigments in crude vegetable oil. Pure Appl Chem. 67, 1781-1787. http://dx.doi.org/10.1351/pac199567101781.

Ranalli A, De Mattia G, Ferrante ML. 1997. Comparative evaluation of the olive oil given by a new processing system. Int. J. Food Sci. Technol. 32, 289-297. http://dx.doi. org/10.1046/j.1365-2621.1997.00116.x.

Reboredo-Rodrìguez P, Gonzàlez-Barreiro C, Cancho-Grande B, Simal-Gàndara J. 2014. Improvements in the malaxation 
process to enhance the aroma quality of extra virgin olive oils. Food Chem. 158, 534-545. http://dx.doi.org/10.1016/j. foodchem.2014.02.140.

Rotondi A, Bendini A, Cerretani L, Mari M, Lercker G, Toschi TG. 2004. Effect of olive ripening degree on the oxidative stability and organoleptic properties of $\mathrm{cv}$. Nostrana di Brisighella extra virgin olive oil. J. Agric. Food Chem. 52, 3649-3654. http://dx.doi.org/10.1021/jf049845a.

Ryan D, Robards K. 1998. Phenolic compounds in olives. Analyst, 123, 31-44. http://dx.doi.org/10.1039/a708920a.

Serra-Majem L, Ngo de la Cruz J, Ribas L, Tur JA. 2003. Olive oil and the Mediterranean diet: beyond the rhetoric. Eur. J. Clin. Nutr. 57, 2-7. http://dx.doi.org/10.1038/sj.ejen.1601801.

Snedecor GW, Cochran WG. 1979. Statistical methods. 6th Ed. The Iowa State University Press. Ames. Iowa. USA.

Tateo F, Bononi M. 2004. Guida all'Analisi Chimica degli Alimenti vol. 3. Oli e Grassi Vegetali ARS Edizioni Informatiche, Milano. ISBN: 9788889260067.

Uceda M, Frías L. 1975a. Épocas de recolección. Evolución del contenido graso del fruto y de la composición y calidad del aceite. in: IOOC (Ed.). Proceedings of II Seminario Oleícola International. Córdoba. Spain.
Uceda M, Frías L. 1975b. Harvest dates. Evolution of the fruit oil content. oil composition and oil quality. En: Proceedings del Segundo Seminario Oleicola Internacional. COI. Cordoba. $125-128$.

Uceda M, Frías ML, Ruano MT. 1992. Diferenciación de variedades de aceituna por la composición ácidica de su aceite. In: Abstracts of the First International Symposium on Olive Growing. Córdoba. Spain. pp. 35-38.

Visoli F, Galli C. 1998. Olive oil phenols and their potential effects on human health. J. Agric. Food Chem. 46. 4292-4296. http:// dx.doi.org/10.1021/jf980049c.

Waterman E, Lockwood B. 2007. Active components and clinical applications of olive oil. Altern Med Rev. 12, 331-342. PMID:18069902.

Zamora R, Alaiz M, Hidalgo FJ. 2001. Influence of cultivar and fruit ripening on olive (Olea europaea) fruit protein content. Composition and antioxidant activity. J. Agric. Food Chem. 49, 4267-4270. http://dx.doi.org/10.1021/ jf0104634.

Zinnai A, Venturi F, Calamita Y, Andrich G. 2007. La criomacerazione prefermentativa nella produzione di vini di qualità. Ind. Bev. 209, 227-232. 